\title{
Headache and specific CT finding of bilateral pallidum
}

\section{Yasuyuki Taooka*, Yusuke Higashi and Gen Takezawa}

Department of general medicine, Akiota hospital, Hiroshima, Japan

A 46-year-old man without any previous history consulted to our hospital complained of delirium and headache. 2-week prior to visit, he noticed headache and general fatigue. 1-week prior, his family felt that content of his speech was irrational. Specific abnormal findings were not recognized on physical examination and laboratory data. Blood laboratory examination showed as following; white blood cell count $7,200 / \mathrm{mL}$, hemoglobin $14.7 \mathrm{~g} / \mathrm{dL}$, platelet count $224,000 / \mathrm{mL}$, total protein $6.9 \mathrm{~g} / \mathrm{dL}$, albumin $4.4 \mathrm{~g} / \mathrm{dL}$, AST $32 \mathrm{IU} / \mathrm{mL}$, ALT $30 \mathrm{IU} /$ $\mathrm{mL}, \mathrm{LDH} 202 \mathrm{U} / \mathrm{mL}$ (normal range: 106-211) fasting blood sugar level $107 \mathrm{mg} / \mathrm{dL}, \mathrm{Na} 141 \mathrm{mEq} / \mathrm{L}, \mathrm{K} 3.5 \mathrm{mEq} / \mathrm{L}, \mathrm{Cl} 107 \mathrm{mEq} / \mathrm{L}, \mathrm{Ca} 9.3 \mathrm{mg} /$ dL C-reactive protein $0.2 \mathrm{mg} / \mathrm{dL}$, Vitamin $\mathrm{B}_{1} 31 \mathrm{ng} / \mathrm{mL}$ (normal range: 24-66), Vitamin $B_{12} 780 \mathrm{pg} / \mathrm{mL}$ (normal range: 24-66), and folic acid $7.5 \mathrm{pg} / \mathrm{mL}$ (normal range: 3.6-12.9). And, atrial blood gas analysis showed as following; $\mathrm{pH} 7.44, \mathrm{PaCO}_{2} 34 \mathrm{mmHg}, \mathrm{PaO}_{2} 95 \mathrm{mmHg}$, $\mathrm{HCO}_{3}{ }^{-} 22.4 \mathrm{mmol} / \mathrm{L}$, base excess $0.1 \mathrm{mmol} / \mathrm{L}$, and $\mathrm{COHb} 0.4 \%$ (normal range $0-0.8$ ). Cerebral CT showed symmetrical low-density area on bilateral pallidum (Figure 1a), and cerebral MRI (T2-weighted image) showed high intensity area on the same lesion (Figure $1 \mathrm{~b}$ ). When recognizing bilateral basal ganglia abnormalities on MRI, causes should be considered as following, toxic diseases, metabolic diseases, vascular diseases, chronic infectious diseases, and degenerative diseases [1]. After careful medical interview, we diagnosed this case as his having chronic carbon monoxide intoxication. 4-week ago, he used wooden stove in closed-room. Since arterial $\mathrm{COHb}$ showed normal range in chronic carbon monoxide intoxication like this case, diagnosis of chronic intoxication is difficult without information of exposure of carbon monoxide [2]. Although incidence of carbon monoxide intoxication is not rare, diagnosis of chronic intoxication is difficult without information of exposure of carbon monoxide [2,3]. The diagnosis of acute carbon monoxide intoxication is based on known $\mathrm{CO}$ exposure and blood $\mathrm{COHb}$ level [3], but arterial $\mathrm{COHb}$ showed

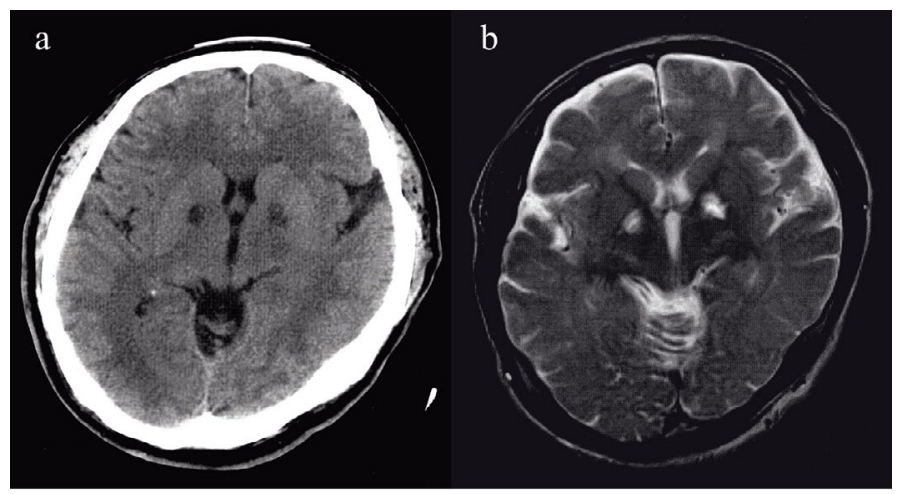

Figure 1. (a) Cerebral CT: Symmetrical low density area was recognized on bilateral basal ganglia, pallidum. (b) Cerebral MRI (T2-weighted image): High intensity area was recognized on the same lesion with (Figure 1a), bilateral pallidum normal range in chronic carbon monoxide intoxication like this case. In elderly cases, symptoms of chronic carbon monoxide intoxication may be misdiagnosed as dementia. Globus pallidus is the most common site of bilateral symmetrical abnormality of carbon monoxide intoxication [4]. High intensity area (MRI, T2-weighted image) on pallidum represents necrotic or demyelinating change [2]. Episode of $\mathrm{CO}$ exposure, neurological disturbance, and symmetrical bilateral basal ganglia abnormalities on MRI highly suggest the possibility of chronic carbon monoxide intoxication. Cerebral MRI is useful for diagnosing of chronic carbon monoxide intoxication sequelae, therefore physicians should be aware of its clinical features.

\section{Author's contributions}

YT and YH obtained the clinical data and YT, YH and GT contributed in critiquing the manuscript. The corresponding author, $\mathrm{YT}$ is the guarantor of submission.

\section{Conflicts of interest}

The authors declare that we have no competing interests.

\section{Ethical approval}

Not required.

\section{Funding}

None.

\section{Informed consent}

Informed consent was obtained from the patient for publication of this study.

\section{Copyright transfer}

The authors declare that the copyright to this article is transferred to Global Imaging Insight when this article is accepted for publication.
References 1. Lim CC (2009) Magnetic resonance imaging findings in bilateral basal ganglia
lesions. Ann Acad Med Singapore 38: 795-802.
2. Beppu T (2014) The role of MR imaging in assessment of brain damage from carbon monoxide poisoning: a review of the literature. AJNR Am J Neuroradiol 35: 625-631. [Crossref]

${ }^{\star}$ Correspondence to: Yasuyuki Taooka, Department of general medicine, Akiota hospital, Shimodomo-Gohchi 236, Akiota-Cho, Yamagata-Gun, Hiroshima, 731-3622, Japan, Tel. +81-826-22-2299, Fax: +81-826-22-0623, E-mail: taooka-alg@umin.ac.jp

Key words: MRI, chronic carbon monoxide intoxication, basal ganglia

Received: March 18, 2019; Accepted: April 01, 2019; Published: April 03, 2019 
3. Ernst A, Zibrak JD (1998) Carbon monoxide poisoning. $N$ Engl J Med 339: $1603-$ 1608. [Crossref]
4. O’Donnell P, Buxton PJ, Pitkin A, Jarvis LJ (2000) The magnetic resonance imaging appearances of the brain in acute carbon monoxide poisoning. Clin Radiol 55: 273280.

Copyright: (C2019 Taooka Y. This is an open-access article distributed under the terms of the Creative Commons Attribution License, which permits unrestricted use, distribution, and reproduction in any medium, provided the original author and source are credited. 